\title{
REPUBLIC OF SERBIA TOWARDS THE EUROPEAN TERRITORIAL COHESION AND CROSS-BORDER COOPERATION - WITH SPECIAL FOCUS ON VOJVODINA
}

Zsuzsanna FEJES, PhD, associate professor in law and political science University of Szeged, Faculty of Law

National University of Public Service, Faculty of Public Administration Address: $\quad$ H-6720 Szeged, Tisza Lajos krt 47.

Phone: $\quad+36305877443$

E-mail: $\quad$ zsuzsanna.fejes@gmail.com 


\title{
REPUBLIC OF SERBIA TOWARDS THE EUROPEAN TERRITORIAL COHESION AND CROSS-BORDER COOPERATION - WITH SPECIAL FOCUS ON VOJVODINA
}

Keywords: European intergration, Multi-level Governance, Territorial governance, European cohesion policy, European Groupings of the Territorial Cooperation (EGTC), Euroregion

\begin{abstract}
:
The intensity of the cooperation beyond borders in Central-Europe and South-East-Europe is lower than in Western-Europe because the nationalizing of the states and the homogenization processes are barriers in front of the developing of the border regions. European territorial cooperation is not possible without decentralisation. The European Union has established a new legal instrument, a new form of cooperation of the European territorial cooperation, namely European Groupings of Territorial Cooperation (2007-13; Objective 3, Regulation $1082 / 2006 / E C)$. It substantially contributes to European integration and to implementation of cross-border strategies. Furthermore, it brings EU policies closer to people; it means European, political, institutional and sociocultural added value. Successfully strengthened territorial cooperation needs an appropriate legislative framework in terms of local governance, local administrative reforms and capacity building. To overcome obstacles and barriers created by borders due to national law and the different administrative structures and competences is the willingness of local and regional authorities.

Vojvodina has a special location among the regions of Carpathian Basin. Due to its historical, ethnic, cultural and economic heritage, Vojvodina is one of the most valuable towards European Union, so called ,gate" of Serbia. The aim of the study is to present the position and possibilities of Vojvodina in the European territorial cooperation from two aspects:

- the new modes of governance, especially the territorial governance, during the core competences of different administrative levels of the European territorial cohesion, taking into account the perspectives of Europeanization (decentralisation and regionalisation) in a heterogenic Union.

- the institutionalisation and the future of the DKMT Euroregion and the Banat-Triplex Confinium EGTC from the aspect Vojvodina, because these co-operations are significant component of the European integration process.

In terms of institutional development the cross-border co-operation calls for partnership and high level of cooperation on behalf of participants and stakeholders that stems from the acceptance and practical adaptation of the principles of multi-level governance and good local governance. EGTCs are generally established to bring together authorities from different administrative levels, including regions, communities or municipalities to act together as one. Through the creation of this legal framework, partners from different countries and different administrative levels can have one common voice in regional, national or international settings and take joint decisions. The conditions of the multi-level governing are primarily determined by the states thus these conditions should be provided by the countries for the local and regional governments to make them possible to join to the European integration and decision-making processes. The conditions of the multi-level governing are primarily determined by the states thus these conditions should be provided by the countries for the local and regional governments to make them possible to join to the European integration and decision-making processes.
\end{abstract}

\section{INTRODUCTION}

Borders are the scars of History (AEBR, 2004, Preamble 3). The wide range of problems and opportunities on both sides of borders in wider Europe makes cross-border cooperation indispensable. The territorial cooperation forms fulfil an increasingly significant role along the internal and external border of the European Union, and during the process of sub-national integration these models gain more and more importance 
concerning the development policy, the cohesion policy and the neighbourhood policy of the European Union. This topic is especially current since a process in European integration has already started, in the course of which the former governing system based on national sovereignty is gradually transformed, while the local and regional levels strengthen both their political and decision-making powers.

Cooperation along the borderlines is a tool of the cohesion and regional policy of the European Union. The importance of cooperation systems evolving along the external and internal borderlines of the EU has been increasing since the eastern enlargement (in 2004 and 2007, 2013). In Europe, more than $40 \%$ of the areas are border regions, inhabited by more than one third of the population, which increases the importance of the EU strengthening its economic influence and its subsidy policy in these areas. The purpose of the EU is to improve cooperation between communities along the borderlines, within the whole of Europe (CoR, CdR 89/2009).

New regionalism as a complex phenomenon was a more perfect form of democracy and model for the future of Europe with converging regions (Keating, 1998). It is not only a myth but is based on the empirical reality of the various types of regions. In practice, regions have to face the heterogeneity of the rising economic, social, political and cultural interests. However, the regionalisation process has more or less confirmed the concept of three-level - or tripartite - structure of the EU polity, consisting of the trans-national, national (centralistic) and regional (decentralised) layers with a strong demand for partnership on the regional level that has proven to be a genuine 'intermediary' level. Further on, the post-modern EU society has been based on multiple identities and communities, with their own interest representation. Thus only the most perfect regions can become one of these newly borne communities.

Vojvodina has a special location among the regions of Carpathian Basin. Due to its historical, ethnic, cultural and economic heritage, Vojvodina is one of the most valuable towards European Union. so called „gate” of Serbia. Next to the emotional relations, the common culture and identity, the economic and infrastructural traditions prevail, which has long tradition. The historical intension, geographical proximity and the European infrastructural connections have established the cross-border relations. The rivers (Tisza, Danube and Sava) symbolize the belonging, the strong national identity. (Takács, 2008, p. 123)

The aim of the study is to present the position and possibilities of Vojvodina in the European territorial cooperation from two aspects. 
Firstly, I examine the new modes of governance, especially the territorial governance, during the core competences of different administrative levels of the European territorial cohesion, taking into account the perspectives of Europeanization (decentralisation and regionalisation) in a heterogenic Union. Distinction of competences can be defined on the ground of the regulation system, such as difference between the modes of governance at the international (the Council of Europe), supranational (the European Union), national and sub-national (regional and local) levels.

Hereafter, I analyse the institutionalisation and the future of the DKMT Euroregion and the Banat-Triplex Confinium EGTC from the aspect Vojvodina, because these cooperations are significant component of the European integration process. For the sake of the proper contents and the effectiveness of national and cross-border cooperation schemes, the cooperation between institutions and local municipalities need to be strengthened both at local, regional, Euro-regional and international levels, also including the extension of the partner contacts ranging from settlements up to regions. In terms of institutional development the cross-border co-operation calls for partnership and high level of cooperation on behalf of participants and stakeholders that stems from the acceptance and practical adaptation of the principles of multi-level governance and good local governance. This process has methodological consequences: appropriately applying the „bottom-up” approach in addition to involving the EU member-states and the non-EU Member states concerned. ${ }^{10}$

\section{The sub-national co-operations in Central and South-East Europe (CSEE) - with special focus on Serbia}

In the Central and South-East European states not only the settlements have become fragmented after constitutional and self-government reforms, but usually their interest representation system has also become poor, asymmetrical and fragmented. The weak mezzo-level or "the missing middle" together with institutional weaknesses can prevent local interests to compensate as real power for the stronger and stronger central administrative, political and economic power. The common lessons from the history of the last decade and analysis which show that regionalisation in these countries can only be

10 This research was supported by the European Union and the State of Hungary, co-financed by the European Social Fund in the framework of TÁMOP 4.2.4. A/2-11-1-2012-0001 'National Excellence Program'. 
completed in a general framework of the overall reform of public administration - since the establishment of self-governing, autonomous regions with their own budgeting - will change the entire structure of public administration at all levels and with all players, actors and agencies. Strategic planning, research, expertise for the institutional design of regionalisation is needed but it is not enough. (Soós, 2011, pp. 33-35)

The European Union may support establishing preconditions with a sensitive and differentiating approach to regionalisation policy and instruments in the Union while taking into account the political, legal and societal reality in each part of Europe including the accelerated top-down and not historically developed bottom-up regionalisation in the Central and South-East European.

There are three societal and political preconditions for mature regionalisation:

- nation-wide campaign that advertise it, since the regions are not well known among the population at large;

- $\quad$ historical compromise has to be made with the local power elites in order to avoid their resistance; and

- national political consensus has to be reached as a compromise between the government and opposition on the principles of decentralisation and regionalisation. (Keating, 1998)

The contribution of the local and regional level in cross-border policies is determined by how much the central government broadens their competence in public law. Consequently, the building-up and institutionalisation of cross-border cooperation systems are largely influenced by the differences of legal and administrative systems, bilateral and multilateral agreements signed by central government. During their operation, the sub-national partners act according to the legal system of their own country. And its effect is appreciable mostly at the cross-border co-operations and at the external borders of the European Union.

\section{Legal framework of the cross-border governance}

\subsection{Madrid Convention - Council of Europe}

The Council of Europe has always recognised the crucial importance of democracy at the local and regional level. The Conference of Local Authorities of Europe was created within the Council in 1957. After some time it became the Congress of Local and Regional Authorities, bringing together the elected representatives of the local and regional communities. The Congress is therefore a political assembly composed of representatives 
holding an electoral mandate as members of a local or regional authority appointed each by a specific procedure. Its 318 full members and 318 substitute members, representing over 200000 European municipalities and regions, are grouped by national delegation and by political group. Thus the Congress offers an ideal forum for dialogue where representatives of local and regional authorities discuss common problems, compare notes about their experiences and then put their points of view to the national governments. Serbia is represented in the Congress by a delegation of 7 representatives and 7 substitutes.

It helps the Organisation's new Member States in introducing real local and regional self-government. Speaking for Europe's regions and municipalities, it delivers its support in founding the actual units of local and regional self-government while encouraging consultation and political dialogue between the national governments and the territorial entities. The Congress moreover performs a function of keeping watch on local democracy in Europe, by producing "monitoring reports" on the situation in the Member States. In this way, it verifies the effective application of the principles set forth in the European Charter of Local Self-Government, and of the major principles of local democracy. It is also in charge of monitoring local and regional elections and of setting the standards for Europe in electoral matters.

Now that new states with varying political and economic profiles are coming on the scene, a reappraisal and a redefinition of the goals of the Congress is in progress. For instance, the Congress needs to aid effective organisation of local and regional authorities in new democracies by encouraging regional and trans-frontier cooperation. As promoter of local and regional democracy, since its inception it has produced a body of international treaties such as the European Charter of Local Self-Government, which has become the authoritative international treaty in this sphere.

Serbia signed (2005) and ratified (2007) the European Charter of Local SelfGovernment, which entered into force in 2008. Serbia has signed neither the Madrid Convention (CoE, CETS No. 106), nor its Additional Protocols (CoE, CETS No. 206). The Serbian signature and ratification of the Convention and the Additional Protocols would require the realisation of the effective sub-national cross-border cooperation. The initiatives of the Council of Europe preceded those of the European Union in the field of regional policy and decentralisation. 


\subsection{European Groupings of Territorial Cooperation - European Union}

The lack of unified legal regulation originates from the diversity of the legal systems, and also from the fact that community level regulation settling the legal state of the Euroregions, and securing the acknowledgement of the right of public legal international treaty-making of the local and regional governments, was absent from the legislation of the European Union for a long time. The existing instruments, such as the European economic interest grouping, have proven ill-adapted to organising structured cooperation under the INTERREG initiative during the 2000-2006 programming period. Council Regulation (1083/2006/EC) laying down general provisions on the European Regional Development Fund, the European Social Fund and the Cohesion Fund increases the means in support of European territorial cooperation.

However, the harmonious development of the EU and greater economic, social and territorial cohesion implies the strengthening of cross-border co-operations. The Regulation (EC) No 1082/2006 of the European Parliament and of the Council on a European grouping of territorial cooperation (EGTC) is a response to the lack of legal and institutional instruments, and ensures cooperation facilities for the local and regional authorities and Member States under the acquis communautaire. The EGTC is a new European legal instrument designed to facilitate and promote cross-border, trans-national and interregional cooperation. It is applicable in every member state, even in those that have not signed the Madrid Convention and its Additional Protocols or the special bi-, and multilateral agreements.

The new legal instrument supplements the already existing initiatives and forms of cooperation, although the Euroregion and the working community also remain. The EGTC regulation leads to the strengthening of cross-border cooperation in both European and domestic law, providing the opportunity for the partners in the cross-border co-operations to create structures with legal personality. The members of EGTC can be states, local and regional authorities as well as certain public legal institutions, or associations - these latter may be members if they are located on the territory of at least two Member States. The law applicable for the interpretation and application of the convention is that of the Member State in which the official EGTC headquarters are located.

However, measures were necessary to reduce the significant difficulties encountered by Member States and, in particular, by local and regional authorities in implementing and managing actions of territorial cooperation within the framework of differing national laws and procedures. It is appropriate for an EGTC to be given the capacity to act on behalf of 
its members, and notably the local and regional authorities of which it is composed. The tasks and competencies of an EGTC are to be set out in its convention. It should be specified that the powers exercised by local and regional authorities as public authorities, notably police and regulatory powers, cannot be the subject of a convention. (Soós and Fejes, 2008, pp. 145-157)

At the same time the Treaty does not allow the inclusion of entities from third countries in legislation based on that provision. From the aspect of Serbia the adoption of a Community measure allowing the creation of an EGTC should not, however, exclude the possibility of entities from third countries participating in an EGTC formed in accordance with this Regulation where the legislation of a third country or agreements between Member States and third countries so allow (Regulation, 1082/2006/EC, Preamble 16).

Regions tried to be active participants on the level of the European Union, but because of the different national executive structures, level under regions can enforce their interest. The co-operations of the new economic and social actors got increasing role through the horizontal tendency of the multi-level governance. Owing to this role lobby groups come on the scene, which form cross-border networks. They have increasing role in the mechanism of the European decision-making as well. It can be described with the notion of governance. The democratic participation forms and the efficient governing concept are closely linked to the expansion of sub-national levels. This process results in public policy networks and new formation of territorial policies. (EUI, 2008, pp. 24-45)

\subsection{Vojvodina in cross-borders relations}

According to the Statute of the Autonomous Province of Vojvodina, it is an autonomous province of its citizens living in its territory and shall constitute part of the Republic of Serbia. Vojvodina is a region in which multiculturality, multiconfessionalism and other European principles and values have been traditionally fostered. The Autonomous Province of Vojvodina shall be an inseparable part of the Republic of Serbia. (Statute of the Autonomous Province of Vojvodina, Article 1)

From the point of view of cross-border cooperation the Article 16 is the most essential part, which makes possible the cooperation between regions. According to the Article 16 of the Statute Vojvodina can

- cooperate with territorial communities and other forms of autonomies in other countries, within the scope of foreign policy of the Republic of Serbia and shall be obliged to observe its territorial integrity and legal system. 
- conclude interregional agreements in fields falling within the scope of its competence.

Furthermore, Vojvodina

- may be a member of European and international associations of regions.

- may establish its Representation Offices in European regions and Brussels, upon the approval of the Government, for the purpose of promotion and enhancement of its economic, scientific, educational and tourist capacities, in accordance with the Constitution and law.

In these scopes of duties it has signed cooperation protocol and letter of intent with many regions. It has the most intensive trans-border-relations with country of BácsKiskun, Vukovár-Serem and the Parliament of Styria.

Additionally, Autonomous Province of Vojvodina is the member of the Assembly of European Regions (AER) since 2002, whose main duty is the union of the European regions, stressing of the European interests and the initiation of the solidarity between the member states of the EU and the third countries. The AER supports the EU programmes, which would like to advance the close-cooperation of the regions of Europe. It helps the decentralisation and democratization process of the administrative system of the SouthEast European countries. It would like to urge the cooperation between the countries of the area with training programs, initiation of the local and regional actors. With the active assistance in the integration process, the AER would like to serve mediatory role between the EU and the countries which declared their EU-accession. It would like to help the regions of Central-Eastern-Europe and Southeast-Europe to approach to the EU. Through the membership it is possible the quicker joining to the European integration processes and the recognizing of the application the cooperation of European policies and the legislation.

In 2008 Serbia signed the European Partnership Agreement regarding the strengthening of the cross-border relations, which makes possible the participation in the IPA (Instrument of Pre-Accession Assistance) programmes. The experiences in the realization of the INTERREG Community Initiative and the Phare CBC programmes in the period 20042006 mean basis to the fulfilment of these programmes. The IPA program set its aim, support the structural and cohesion policy of the pre-accession countries, in the programming period of 2007-2013. In this scope, in the regions placed along external borders the candidate and the potential candidate (Serbia) countries can get aiding. 
The European Committee passed the Hungary-Serbia IPA Cross-Border Cooperation Program in 25 Marc 2008. In the framework of the program, a total of EUR 50.1 million community support is available for seven years. Despite of that the program concerns the programming period of 2007-2013, the first invitation for application in Serbian-Hungarian context was only at the end of 2009.

\section{Vojvodina in the European territorial cooperation: Euroregion vs. EGTC}

In the repertoire of the European Union established a legal model of the cross-border co-operations, although the real legal harmonization did not occur until now, because the order can be applied in the case of some condition. This is the reason, why remains the traditional institutional forms in the euro-regional cross-border relations in the non-EU member countries; this situation sets the parallelism and queries the success of the unit. The question arises: which form of cooperation is more efficient in the formation of Vojvodina's regional relations - Euroregion or EGTC?

\subsection{The DKMT Euroregion}

The Danube-Kris-Mures-Tisa Euroregion (hereafter: DKMT) is an organization of the Hungarian-Romanian-Serbian border area which was established in 21 November 1997 with the participation of four Hungarian counties (Békés, Bács-Kiskun, Csongrád and JászNagykun-Szolnok), four Romanian counties (Arad, Hunyad, Krassó-Szörény and Temes) and the Serbian Autonomous Province of Vojvodina. ${ }^{11}$

A long preparatory work took place before the merger of the institutions of the Euroregion and it led to bilateral cooperation agreements that helped to unify the three different legal, political and public administration systems into one unit. The triple-border area is a sensitive place from the geo and security political point of view and the ethnics are heterogeneous. At the same time the area is unified from natural, economic, geographical and cultural historical point of view.

The South part of The Danube-Tisza Interfluve, Körös River and the Territory of Maros River have a homogeneous natural capability and they were an independent economical

\footnotetext{
${ }^{11}$ The agreements between Temes and Csongrád County and between Arad and Békés County were concluded in 1992; the agreements between Bács-Kiskun, Békés, Csongrád, Jász-Nagykun-Szolnok Counties and Vojvodina were concluded in 1994 and the Euroregion was established in 1997.

Jász-Nagykun Szolnok, Békés, and Hunyad County exited from the cooperation later.
} 
unit until the World War I. The differences in the structures of the public administration and in the institutions, the different national and political interests and the shortage of the financial sources were the barriers of the cooperation. On the other hand the similarities in the evolution of the culture, language and history, the willing for join to the European processes and the chance for the faster economic growth helped to make the frame of the cooperation. (Nagy, 2009, pp. 472-473)

The Euroregion was established by the mutual recognition of the interests of the leaders of the counties, although the operation of the Euroregion was already slow and problematic at the beginning, the ongoing processes of the Yugoslavian Crisis made the Euroregion temporary unable to work in 2000 and 2001. Vojvodina wasn't able to fulfil its obligations even formally which was undertaken in the cooperation.

The cooperation went through a structural reform in 2003. The Euroregion evolved into an organization with two actors because of the reforms and the new structure: there is a consultative political forum (Assembly) and there is an incorporated working station with legal entity and important financial status (Euroregion Development Agency) next to each other. The founders practice their rights and pass resolutions about ideas of the developing through the meeting of the members which can be implemented by the organization. The reform resulted that the Coordination Committee turned into a part of the classic Euroregion structure which is an organization for ensuring the effectiveness of the preparing for the resolutions and it contains 3 people to help into the operation of the DKMT. On the other hand it was established the DKMT Euroregion Development Agency (later DKMT Nonprofit Public Benefit Limited) which has legal entity, has the authority to manage and prepare the common developing programs. The goal of the structure is to divide the business association with legal entity and the political organization of the regional cooperation.

The territorial development strategy of the DKMT Euroregion was approved in 2005 based on the participation of the civil economic actors and the local government which strategy has considered their interests and it defined the long-time goals of the cooperation. (Statute of the DKMT Euroregion, 2003, 2005, 2009)

The operation of the Euroregion is still not proper these days: in spite of the structural reform, the different political systems, the centralized, bureaucratic competences of the member states are still barriers in front of the cooperation. Although the goals of the cooperation would be able to provide adequate content for the cooperation, the participants don't live with the advantages of the triple-border area. 
The last years of the operation of the DKMT prove that the regional relationship overstepped the competent of the founder counties and provinces. The smaller forms of the bilateral and trilateral interregional cooperation should be strengthened and also the cooperation of the micro-regions, cities and municipals and the "gateway" role of the big and middle-sized cities and the transfer functions with the ability to connect municipals should be stronger (Ricz-Gábrity, 2010).

\subsection{Banat-Triplex-Confinium EGTC}

The establishment of the Banat-Triplex-Confinium Limited Liability EGTC (hereinafter: BTC-EGTC) was started in 10 December 2009 because of the structural problems with the DKMT Euroregion and it was initiated by the local governments of Mórahalom and the Romanian Zsombolya. 37 Hungarian and 37 Romanian municipalities joined to the concept and few self-governments of Vojvodina and municipalities from Bácska and Bánát (would) took part in this concept. The cooperation was established officially in 11 January 2011 based on the aforesaid 1082/2006/EK EGTC regulation of the European Union but without the members of Vojvodina.

The difficulties around the establishment of the EGTC show us the common problems along the peripheral borders of the EU: the EU EGTC regulation cannot be applied directly to the member states which are neighbours with non-EU countries but they would like to cooperate with them. The following conditions should be fulfilled to turn the local governments of Vojvodina into members of the EGTC:

- There should be at least two participants from EU member states,

- It is necessary for the involving of interested partners from third countries that the third country (in this case Serbia) should pass a law in its national legal system which can permit the establishing of the EGTC because the approval from every founder country is compulsory; or

- the member states (Hungary and Romania) and the non-EU member third country (Serbia) should conclude a cooperation arrangement because they can empower their authorities whit that document to shape a cooperation beyond borders. (Convention of the BTC-EGTC, Chapters II-IV) 


\subsection{The chances of forming an EGTC in Vojvodina, the reform of the EGTC regulation}

The "European territorial cooperation" is a special goal in the European cohesion policy between the 2007 and the 2013 financial term which makes the horizontal dimension of the EGTC more important thus the EGTC is the most crucial European instrument for the territorial cohesion. The EGTC is an experimental territory of the multi-level governing system which makes a two-level communication channel that works with the "theory of initiating from the lower level" and it is a mediator for the issues about borders. The diversity of the forms of the cooperation in the EGTC is an essential condition of the multilevel governing and the advantage of this system is that the interested parties can decide that which form of cooperation is more suitable for the improving of their connections beyond borders.

In the case of Vojvodina the chance of establishing the EGTC depends on the partners who would like to cooperate with it because only after the cooperation of two EU member states can the non-EU member state join to the cooperation. This is the first condition which is fulfilled but the other two conditions weren't executed by the central government of Serbia. It can be said that Serbia is still interested in the improving of the HungarianSerbian-Romanian trilateral relationships but it is essential for the Vojvodina's connecting to the BTC-EGTC (which is a legal entity) that Serbia should pass a national law and the authorities of the three countries should approve it.

It is an important issue for Hungary that how Serbia (which is a non-EU state) can join to the EGTC like cooperation that were initiated by the EU member states. This is the reason why it would be important for Serbia to pass the Madrid Convention with its Additional Protocols drawn by the Council of Europe, which would provide a uniform institutionalized form for the cooperation with non-EU members which would fill the current gap of law.

However, the amendment of the EGTC regulation proposes a new legal base for the membership of Third Countries which would make the connection of the non-EU Member easier. The regulation makes it possible for EU Member States and non-EU Member States and their legal entities to be a member of the cooperation irrespectively for that the members are legal entities of one or more countries.

In accordance with the amended Article 3a, an EGTC may be made up of members drawn from the territory of only one Member State and of one third country or overseas territory, where that Member State considers such an EGTC consistent with the scope of its 
territorial cooperation or bilateral relations with the third country or overseas territory. Namely, there is no need for bilateral agreements between countries which are already connected to the Madrid Convention. However, in the case when the Madrid Convention is not signed, a bilateral agreement is enough between drawn from the territory of only one Member State and of one third country. (COM(2011) 610 final)

In the case of Serbia the EGTC regulation can be passed easier during the integration process to the European Union. This process is urged by the fact that Hungary, Croatia and Romania would like to live with the opportunities of the tenders which is provided by the EGTC cooperation.

\section{CONCLUSION}

It can be summarized that the intensity of the cooperation beyond borders in CentralEurope and South-East-Europe is lower than in Western-Europe because the nationalizing of the states and the homogenization processes are barriers in front of the developing of the border regions. The cooperation beyond borders was evolved along the borders inside the European Union in the last two decades.

European territorial co-operation is not possible without decentralisation. The European Union has established a new legal instrument, a new form of cooperation of the European territorial cooperation (2007-13; Objective 3). It substantially contributes to European integration and to implementation of cross-border strategies. Furthermore, it brings EU policies closer to people; it means European, political, institutional and socio-cultural added value. Successfully strengthened territorial cooperation needs an appropriate legislative framework in terms of local governance, local administrative reforms and capacity building. To overcome obstacles and barriers created by borders due to national law and the different administrative structures and competences is the willingness of local and regional authorities.

On the basis of these my conclusion is that the most appropriate models for institutional cooperation could be those applied by the European Grouping of Territorial Cooperation (EGTC). The EGTC regulation is the first example among EU legal regulations in the course of which a legal instrument grants special rights to local, regional and national public law institutions and civil law organisations of different member states, in order to develop unified structures that can achieve a more efficient cooperation: 
- it represents a new alternative to increase the efficiency, legitimacy and transparency of the activities of territorial cooperation

- it signifies decentralized cooperation, and is built on the year long experience of Euroregional cooperation

- it is an instrument of multi-level governance, and contributes to the quality improvement of local and regional cross-border cooperation

- it may be possible for geographical overlaps to be found in case of the various EGTC-s or for the EGTC-s to be arranged around specific tasks, instead of on a territorial basis.

EGTCs are generally established to bring together authorities from different administrative levels, including regions, communities or municipalities to act together as one. Through the creation of this legal framework, partners from different countries and different administrative levels can have one common voice in regional, national or international settings and take joint decisions. (EGTC Monitoring Report, 2012, pp. 101102) However, the EGTC regulation of the European Union has a paradox nature about Serbia:

- the purpose of the regulation is the balanced and harmonic developing of the inside market of the EU and territorial cohesion but the resources on the local level are less than before and this situation is against democratic processes.

- it makes possible for the sub-national levels to connect to the multi-level governing system and it provides the conditions for the connection to a European level cooperation but using of this opportunities is difficult because the state systems are centralized which shows us the lack of the democratic processes.

The conditions of the multi-level governing are primarily determined by the states thus these conditions should be provided by the countries for the local and regional governments to make them possible to join to the European integration and decisionmaking processes. However, the EU's commitment and the assistance to international documents need to be matched with the dedication of non-EU governments to implement the necessary political and legal reforms, to establish the required administrative capacity, and to cooperate between themselves.

The European territorial networks at local and regional level can make an important contribution to tolerance and building mutual trust via socio-cultural cooperation. Crossborder cooperation therefore will remain an indispensable factor for facilitating 
partnerships between neighbouring countries. Partnerships of this kind can build new good multi-level neighbourly relations on the borders.

\section{REFERENCES}

European University Institute Florence (2008). Study on the Division of Powers between the European Union, the Member States, and Regional and Local Authorities. Brussels: The Committee of the Regions. ISBN: 978-92-895-0449-2

Keating, M. (1998). The New Regionalism in Western Europe. Cheltenham: Edward Elgar.

Nagy I. (2009). Területfejlesztés és területi együttmüködés a Dél-Alföldön. In Nagy G. (ed.), Dél-Alföld. A Kárpát-medence régiói 10, Pécs-Budapest: MTA RKK-Dialóg Campus.

Ricz A. \& Gábrity Molnár, I. (2010). Vajdaság régiókapcsolatai a Dél-Alfölddel. In Soós, E. \& Fejes Zs. (eds.), Régió a hármashatár mentén (pp. 76-93). Szeged: SZTE ÁJK Politológiai Tanszék.

Soós, E. (2011). Kohéziós politika. Szeged: Pólay Elemér Alapítvány.

Soós, E. \& Fejes, Zs. (2008). Hungarian Experiences of Cross-Border Cooperation. Fundamentum, 12 (5), pp.123-157.

Takács Z. (2008). Területi szerveződés és regionalizáció Szerbiában. In Gábrity Molnár I.Mirnics Zs. (eds.), Regionális erőnlét. A humánerőforrás befolyása Vajdaságban. Szabadka: MTT Könyvtár 13.

\section{Documents}

Association of the European Border Region: European Charter for Border and CrossBorder Regions, New version, Gronau, October 7, 2004. Retrieved September 15, 2013, from http://www.aebr.net

Council of Europe CETS No. 106 of 21/05/1980 on European Outline Convention on Trans-frontier Cooperation between Territorial Communities or Authorities, Madrid

Council of Europe CETS No. 206 of 16/11/2009 on Protocol No. 3 to the European Outline Convention on Transfrontier Co-operation between Territorial Communities or Authorities concerning Euroregional Co-operation Groupings (ECGs), Utrecht

Convention of the BTC-EGTC, Retrieved October 20, 2013, from http://www.fovarositorvenyszek.hu/sites/default/files/eutert/egyezmenyek/1banat_eg yez.pdf

EGTC Monitoring Report 2012. Brussels: The Committee of the Region, EU. Retrieved October 20, 2013, from https://portal.cor.europa.eu/egtc/enUS/discovertheegtc/Documents/Monitoring\%20Report\%202012/EGTC_Monitoring Report_2012.pdf

Proposal for Regulation of the European Parliament and of the Council amending Regulation (EC) No 1082/2006 of the European Parliament and of the Council of 5 July 2006 on a European grouping of territorial cooperation (EGTC) as regards the clarification, simplification and improvement of the establishment and implementation of such groupings. European Commission COM(2011) 610 final

Regulation (EC) No 1082/2006 of the European Parliament and of the Council of 5 July 2006 on a European grouping of territorial cooperation (EGTC)

Statute of the Autonomous Province of Vojvodina. Retrieved September 15, 2013, from http://www.puma.vojvodina.gov.rs/dokumenti/Engleski/pravni_akti/Statut_APV_en. pdf 
Statute of the DKMT Euroregion, 2003, 2005, 2009. Retrieved October 20, 2013, from http://www.dkmt.net/hu/index.php?page=euroregio

The Committee of the Regions Own-initiative Opinion CdR 89/2009 of 17-18/06/2009 on the Committee of the Regions' White Paper on Multilevel Governance 